\title{
A VOYAGE UP THE RIVER AMAZON INCLUDING A RESIDENCE AT PARÁ (CHAPTER XXIII)
}

\author{
William H. Edwards
}

Tradução de:

Luana Ferreira de Freitas 1 ${ }^{1}$ Universidade Federal do Ceará, Fortaleza, Ceará, Brasil/CNPq

Kelvis Santiago do Nascimento $\underline{2}$ ²Universidade Federal do Ceará, Fortaleza, Ceará, Brasil

\section{CHAPTER XXI}

Description of Marajo - Cattle - Descrição de Marajó - Gado - OnTigers - Alligators - Snakes - Antas - ças - Jacarés - Cobras - Antas Wild ducks - Scarlet Ibises - Roseate Patos selvagens - Ibis-escarlates Spoonbills - Wood Ibises - Other - Colhereiros - Tuiuiús - Outros birds - Island of Mixiana - Indian pássaros - Ilha Mexiana - Cemitéburial places - Caviana - Macapá - rios indígenas - Caviana - Macapá Bore or Pororoca - Leave Jungcal for - Pororoca - De Juncal à colônia the rookery - A sail among the trees de aves - Navegação por entre as - Alligators - The rookery - Return - árvores - Jacarés - Colônia de aves $\mathrm{Na}$ alligator's nest - Adie uto Jungcal - Volta - Ninho de jacaré - Adeus - Violence of the tide - Loading cattle a Juncal - Violência da maré - Em- Voyage to Pará.

The length of the Island of Marajo is about one hundred and twenty miles; é de cerca de 120 milhas $^{1}$, sua larits breadth averages from sixty to gura varia de 60 a $80^{2}$. Muito dela eighty. Much of it is well wooded, é coberta de floresta, mas a maior 
but far the larger part is campo, parte é pasto, coberto durante a escovered during the wet season with tação de chuvas por mato alto. Ducoarse, tall grass. At that time, the rante essa época, toda a ilha é pouco whole island is little more than a mais que um labirinto de lagos. $\mathrm{Na}$ labyrinth of lakes. In summer, the seca, a água superabundante é dresuperabundant waters are drained nada por inúmeros igarapés e, com by numerous igaripés, and, rain a chuva rara, essa superfície encharrarely falling, this watery surface is cada é transformada em um jardim exchanged for a garden of beauty, de beleza, em algumas partes, e em in some parts, and into a desert, deserto, no pasto. A população da upon the campos. The population ilha é grande, consistindo, em sua of the island is large, consisting maioria, de indígenas e mestiços. mostly of Indians and half-breeds. Algumas vilas, contudo, são de taSome of the towns, however, are of manho considerável, mas a maior considerable size, but most of the parte da população mora ao longo da inhabitants are scattered along the costa e nos igarapés. Quatrocentas coast and upon the igaripés. Four mil cabeças de gado vagueiam pelo hundred thousand cattle roam over pasto, de donos diferentes, os diverthe campos, belonging to various sos rebanhos são diferenciados por proprietors, the diferente herds marcas distintas ou marcações. A being distinguishable by peculiar propriedade da qual Juncal faz parte marks, or brands. The estate of tem um total de trinta mil cabeças de which Jungcal forms part, numbers gado, e um grande número de indíthirty thousand cattle, and a great genas e negros são empregados no number of Indians and blacks are seu cuidado, mantendo o gado junemployed in their care, keeping to, guiando-os em épocas propícias them together, driving them up at para a marcação e reunindo aqueles proper seasons to be marked, and designados para a exportação para a collecting such as are wanted for cidade. Esses homens tornam-se exexportation to the city. These men tremamente apegados a esse estilo de become extremely attached to this vida selvagem; são de uma raça deswild life, and are a fearless, hardy temida, resistente, admiráveis cavarace, admirable horsemen, and leiros e exímios no laço. Quando os expert with the lasso. When horses cavalos abundavam, era comum conabounded, it was customary to duzir o gado comercializável ao lado 
drive the marketable cattle towards the Pará side of the island, whence transmission to the city was easy; but, at present, they are shipped from Jungcal, or other places still more remote, thus causing great waste of time, and ruining the quality of the beef. The cattle are of good size, but not equal to those of the South. Great numbers of young cattle, and old ones unable to keep up with the herd, are destroyed by the 'tigres,' which name is applied without much precision to different species. The black tiger is seen occasionally ; the Felis onça is most common of all. Neither of these is known to attack man ; and in their pursuit, the islanders exhibit great fearlessness and address, never hesitating to attack them when driven to a tree, armed with a tresádo fastened to a pole. At other times, they overtake them upon the campos, running them down with horses, and lassoing them. Once thus caught, the tiger has no escape. $\mathrm{He}$ is quickly strangled, his legs are tied, and, thrown over the horse's back like a sack of meal, he arrives at the hut of his captor. Here a dash of water revives him, but his efforts to escape are futile. An Onça taken in this manner, was brought to Pará for Mr. Campbell. He was da ilha próximo ao Pará, de onde a transferência para a cidade era fácil; mas, atualmente, os animais são embarcados em Juncal, ou outros lugares ainda mais remotos, causando, portanto, um grande desperdício de tempo e comprometendo a qualidade da carne. O gado é de bom tamanho, mas não se iguala àquele do sul. Grande número do gado mais novo, e do velho incapaz de manter o ritmo da boiada, é morto pelas onças ${ }^{3}$, animal cujo nome é aplicado sem muita precisão a diferentes espécies. A onça-preta é vista de vez em quando; a onça-pintada é a mais comum de todas. Nenhuma dessas é conhecida por atacar o homem, e, em seu encalço, os habitantes da ilha exibem grande destemor e prontidão, nunca hesitando em atacá-las com um terçado fincado em uma haste, quando acuadas em uma árvore. Outras vezes eles apanham-nas nos pastos, alcançando-as com cavalos e laçando -as. Uma vez capturada, a onça não tem escapatória. Ela é rapidamente sufocada, suas patas amarradas e, sendo jogada sobre o dorso do cavalo como uma saca de farinha, ela chega na cabana de seu caçador. Ali ela é reanimada com um pouco de água, mas seus esforços para escapar são em vão. Uma onça capturada desta maneira foi trazida ao Pará para o 
strangled both on being take non and off the canoe, and after being revived, was marched upon his fore legs through the streets, two men holding each a hind leg, and others guiding him by the colar upon his neck.This animal was afterwards brought to New-York by Capt. Appleton. Frequently, young tigers are exposed for sale in the market, and one of these was our fellow passenger in the Undine, upon our return. We read in works of Natural History, most alarming accounts of the fierceness of the Brazilian felines, but as a Spanish gentleman remarked to us, of the Jaguar, 'those were ancient Jaguars, they are not so bad now-a-days.'

The cattle have another enemy in the alligators, who seem to have concentrated in Marajo from the whole region of the Amazon, swarming in the lagoons and igaripés. There are two species of these animals, one having a sharp mouth, the other a round one. The former grow to the length of about seven feet only, and are called Jacaré-tingas, or King Jacarés. This is the kind eaten. The other species is much larger, often being seen twenty feet in length, and we
Sr. Campbell ${ }^{4}$. Ela foi sufocada tanto ao ser colocada quanto retirada da canoa, e após ser reanimada, foi conduzida sob as patas dianteiras pelas ruas, com dois homens cada segurando uma pata traseira, e outros guiando-a pela coleira em seu pescoço. Esse animal foi trazido posteriormente a Nova York pelo capitão Appleton. Com frequência, onças jovens são expostas à venda na feira, e uma dessas foi passageira conosco na Undine, quando do nosso retorno. Lemos em livros de História Natural os mais alarmantes relatos sobre a agressividade dos felinos brasileiros, mas, como um cavalheiro espanhol comentou conosco, "aquelas eram onças antigas, elas não são tão más hoje em dia".

Outro inimigo do gado são os jacarés, os quais, de todas as regiões da Amazônia, parecem ter se concentrado em Marajó, infestando lagoas e igarapés. Há duas espécies desses animais, uma que possui um focinho pontudo e a outra, arredondado. O primeiro cresce apenas até os sete pés de comprimento ${ }^{5}$ e são chamados Jacaretinga ou Jacaré de óculos ${ }^{6}$. Esse é o tipo comestível. A outra espécie é muito maior, sendo vista com frequência alcançar os vinte pés de comprimento ${ }^{7}$, e fomos 
were assured by Mr. Campbell, that assegurados pelo Sr. Campbell que skeletons of individuals upwards às vezes são encontrados esqueletos of twenty-five feet in length are dessa espécie maiores que os vinte e sometimes encountered.

In the inner lakes, towards the close of the rainy season, myriads of ducks breed in the rushes, and here the alligators swarm to the banquet of young birds. Should an adventurous sportsman succeed in arriving at one of these places, he has but a poor chance of bagging many from the flocks around him, for the alligators are upon the alert, and the instant a wounded bird strikes the water, they rush en masse for the poor victim, clambering over one another, and crashing their huge jaws upon each others' heads in their hasty seizure. Late in the wet season, they lay nas cabeças dos outros, em sua their eggs, and soon after, instead convulsão precipitada. Mais tarde, of becoming torpid, as would be na estação úmida, os jacarés põem the case in a colder climate, bury seus ovos, e logo depois, em vez themselves in the mud, which, de hibernarem, como seria o caso hardening about them, effectually em um clima mais frio, eles merrestrains their locomotion, until the gulham na lama, que, quando seca, next rains allow their dislodgment. efetivamente lhes restringe a locoThe inhabitants universally believe, moção até que as próximas chuvas that the alligator is paralyzed with permitam seu deslocamento. Todos a fear at the sight of a tiger, and os locais acreditam que o jacaré fica will suffer that animal to eat off paralisado de medo ao avistar um tiits tail, without making resistence. gre, suportando que esse coma a sua The story is complimentary to the cauda sem resistir. Seja como for, a tiger, at all events, for the tail of the história pende para o lado do tigre, 
alligator is the only part in esteem by epicures.

Snakes spend their summers in the same confinement as alligators, and upon their issuing forth, are said to be very numerous, and often of great size. It was from Marajo, that the anaconda, now or lately exhibited at the American Museum, was brought, and this fellow, as well as the 'Twin Caffres,' we frequently saw at Pará before their transportation to New-York. The largest snake known, of late years, at Pará, was twenty-two feet in length. He was captured upon Fernando's Island, near the city, by the negroes, with a lasso, as he laid upon the shore, basking in the sun. He had long infested the estate, carrying off, one time with another, about forty pigs. Even after being captured and dragged a long way to the house, he coiled his tail around a too curious pig, that we may suppose, was gloating over his fallen enemy, and would have made a forty-one of him, had not the exertions of the blacks forced him to let go his hold.

We never heard an instance of snakes attacking man, and the negroes do not fear an encounter with the temem topar com uma das maiores. pois a cauda do jacaré é a única parte estimada por bon vivants.

As cobras passam o período da seca no mesmo confinamento que os jacarés e, quando surgem, dizem ser em grande número e frequentemente imensas. Foi de Marajó que a sucuri, exibida no American $\mathrm{Mu}-$ seum, foi levada, e a víamos com frequência no Pará, bem como aos "Gêmeos caffres", antes de serem transportados para Nova York. A maior cobra de que se tem notícia, nos últimos anos, no Pará media vinte e dois pés ${ }^{10}$. Ela foi capturada na Ilha Fernando, próximo à cidade, laçada pelos negros enquanto repousava na beira-mar banhando-se ao sol. Já há muito ela importunava a propriedade, levando consigo, um após o outro, cerca de quarenta porcos. Mesmo depois de capturada e arrastada por um longo caminho até a casa, ela enroscou sua cauda em um porco curioso demais que, poderíamos supor, se refestelava com a inimiga caída, e teria feito dele sua o quarenta e um, não fossem os esforços dos negros para obrigar a cobra a soltá-lo.

Nunca ouvimos um caso de cobra atacando homem, e os negros não

$$
\text { temem topar com uma das maiores. }
$$


largest. Snake hunts, doubtless, Sem dúvida há grande interesse nas have exciting interest, as well as caçadas a cobra, assim como em others less ignoble. As elsewhere outras menos desprezíveis. Como remarked, these reptiles are very já dito, esses répteis com muita frequently kept about houses in the frequência são mantidos nas casas city, and may be often purchased in na cidade, e por vezes comprados the market, nicely coiled in earthen na feira, perfeitamente enrolados jars. Southey records an old story to dentro de jarros de barro. Southey this effect : ' that when the anaconda conta uma velha história nesse senhas swallowed an anta, or any of the tido: "que quando a sucuri engole larger animals, it is unable to digest uma anta, ou algum outro animal it, and lies down in the sun till the de grande porte, ela não consegue carcass putrifies, and the urubus, digerir e se deita sob o sol até que a or vultures, come and devour both it and the snake, picking the flesh of the snake to the back-bone, till only back-bone, head and tails be left ; then the flesh grows again over this living skeleton, and the snake becomes as active as before. ' The march of knowledge in this department is certainly onward ; now, gentlemen in Pará believe no more, than that the whole belly and stomach fall out, trap-door like, soon to heal again, and ready for a repetition. In either case, the poor snake is much to be pitied.

The Antas, or Tapirs, are animals not often found upon the mainland, but occasionally observed on Marajo, along the igaripés. They are, by many, considered as consideram anfíbios, mas vivem amphibious, but they live upon the na terra, recorrendo à água apenas 
land, merely resorting to the water for bathing. In size, they resemble a calf of a few months, and when old, are of a brown color. They are remarkable for a proboscislike nose. When tamed, they are extremely docile, and are allowed to roam freely, being taught to return home regularly. One which we saw in this state was small, and marked with longitudinal spots of a light color.

The large Ant Eater is also a dweller on Marajo.

The Ducks breeding upon this Os patos que acasalam na ilha são island are of two kinds, the de dois tipos, o pato-de-papada ${ }^{12} \mathrm{e}$ commong Musk Duck, and the a marreca-cabocla (Anas autumnaMaracas (Anas autumnalis). The lis). Esta aparece em maior número. latter are most numerous. By the No mês de setembro, as aves jovens month of September, the young are já estão bem crescidas, e as velhas well grown, and the old birds are debilitadas devido à perda de suas debilitated from loss of their wing quills. Then, particularly upon Igaripé Grande, on the Pará side, people collect the ducks in great flocks, driving them to a convenient place, and, catching them, salt them down by the canoe load.

Of the water birds frequenting Das aves aquáticas habituais em Marajo, the Scarlet Ibis, and Marajó, o íbis escarlate e o colhethe Roseate Spoonbill, excel all reiro-americano excedem as demais in gorgeousness and delicate em deslumbre e delicada coloração. 
coloring. The Ibises are of the Os íbises são de um escarlate intenbrightest scarlet, excepting the so, exceto pelas extremidades pretas black tips of the wings, and their das asas, e sua aparição, formando appearance, when, in serried fileiras cerradas de uma milha ${ }^{13}$, ranks, the lenghth of a mile, ocorre quando de sua primeira vithey first come to their breeding sita ao local de reprodução, o que, place, is described, as one might como se pode imaginar, é descrito well imagine it, as wonderfully como maravilhosamente esplendomagnificent. They appear, in this roso. Eles aparecem dessa maneira manner, in the month of June, no mês de junho e logo começam and at once, set about the forming a construir seus ninhos. A essa alof their nests. At this time, they tura, possuem uma plumagem perare in perfect plumage, but soon feita, mas logo após começarem a commencing to moult, theyy muda das penas perdem um pouco lose somewhat of their beauty. da beleza. As aves jovens estão The young birds are ready to prontas para partir em dezembro, depart in December, and then, e a família toda então desaparece the whole family disappear from das proximidades, exceto por uns the vicinity, excepting a few poucos indivíduos aqui e ali. No individuals here and there. In Maranhão, a época de reprodução Maranham, the breeding season is ocorre em fevereiro, e nesse mês o in February, and, in that month, capitão Appleton pode encontrá-las Capt. Appleton found them there em grandes números. Algumas vein vast numbers. Sometimes, but zes (ainda que de forma rara), esrarely, they are observed in the sas aves são vistas nos distritos do Gulf districts of the United States, Golfo dos Estados Unidos, embora but they have never been known nunca se tenha sabido de sua reproto breed there. The nests are made dução por lá. Os ninhos, feitos de of small sticks, loosely formed. pequenos gravetos, são frouxamente From two to three eggs are laid, construídos De dois a três ovos são greenish in color, and spotted with postos, sendo esses de coloração eslight brown. verdeada e manchados de marrom.

The Roseate Spoonbills do not Os colhereiros não migram como migrate as do the Ibises, being quite os ibises e são bastante comuns em 
common upon the whole coast, and toda a costa, sendo vistos muitas sometimes being seen far up the vezes distantes do Amazonas no Amazon in summer. The delicate verão. O delicado tom rosa de sua roseate of their general coloring, coloração geral, somada ao carmim with the rich, lustrous carmine of vivo e brilhante de seus ombros e their shoulders, and breast tufts, tufos do peito, bem como a forma as well as the singular formation única de seus bicos, tornam essa ave of their bills, render them objects of great interest as well as beauty. They are seen fishing for shrimps and other small matters allong the edges of the water, or in the mud left exposed by the ebbing tide, and as they eat, grind the food in their mandibles moved laterally. As well as the Ibis, they are exceedingly shy at every season, except when breeding. They breed in the same places with the Scarlet Ibises and the Wood Ibises, and the nests of the three resemble each other in every respect, but in size. The eggs of the Spoonbill are from three to four, large, white, and much spotted with brown. The birds are called by the Brazilians, Colheréiros, meaning spoonbill. The name of the Ibis is Guerra, signifying warrior.

objeto de grande interesse e beleza. Eles são vistos caçando camarões e outros pequenos animais na beira da água ou na lama exposta pela maré baixa, e, quando comem, trituram a comida movendo suas mandíbulas de um lado para o outro. Assim como o íbis, essas aves são extremamente tímidas em qualquer período, exceto na época de reprodução. Os colhereiros se reproduzem nos mesmos lugares que os íbises escarlates e os cabeça-secas, e os ninhos dos três são parecidos em todos os aspectos exceto tamanho. Os colhereiros põem de três a quatro ovos grandes, brancos e com marcas marrons. Elas são chamadas pelos brasileiros de colhereiros, spoonbill em inglês. O nome dos íbis é Guerra, warrior em inglês.

Another of the northern birds here Outra ave do norte que se reproduz breeding, is the Wood Ibis, Tantalus aqui é o cabeça-seca (Tantalus loloculator, much larger than either culator), muito maior que os outros of the above. Its general plumage is dois anteriormente mencionados. white, the tips of the wings, and the Sua plumagem geral é branca, com tail, being a purplish black. By the as extremidades das asas e a cauda 
natives, it is called the Jabirú, which de um preto arroxeado. Ela é chamaname in Ornithologies is more da pelos nativos de jabiru, cujo nome generally applied to the Tuyuyu. It na ornitologia é geralmente mais lays two or three eggs, of a dirty aplicado ao tuiuiú. Essa ave põe de white color.

dois a três ovos de cor branca suja.

Besides these, the Glossy Ibis, Além desses, o íbis-preto (Ibis falIbis falcinellus; the Great Blue ciinellus); a garça-azul-grande ( $A r$ Heron. A. herodias; Night Heron, dea herodias); o socó dorminhoco A. nycticorax; Great American (A. nycticorax); a garça-brancaEgret, A. alba; Snowy Heron, A. grande (Ardea alba); a garça-brancandidissima; Least Bittern, A. ca-pequena ( $A$. candidíssima); o exilis; Purple Gallinule, Black- socoí-vermelho (A. exilis); o frango necked Stilt, and perhaps others -d'água-azul, o perna-de-pau e talcommon in the United States breed vez outras aves comuns nos Estados pon Marajo; as well as a variety Unidos se reproduzem em Marajó, of the same family peculiar to the da mesma forma que uma variedade South.

da mesma família peculiar ao sul.

We found here, also, one of the Também encontramos aqui um dos rarer land-birds of Audubon, the mais raros pássaros do Audubon ${ }^{14}$, Fork-tailed Fly-catcher, Muscicapa o tesourinha, Muscicapa forficatus, forficatus, and were fortunate e tivemos a sorte de descobrir seu enough to discover its nest. This ninho. Este estava perto da água, was near the water, in a low tree, numa árvore baixa, e era feito de and was composed of grass and the grama e partes de alguma plandown of some plant. The eggs were two in number, white, and spotted with brown, at the larger end more particularly, resembling, except in size, those of our King-bird.

ta. Havia dois ovos brancos com manchas marrons mais especificamente na extremidade mais larga, lembrando, exceto em tamanho, os ovos de nosso suiriri-valente.

Generally, the land-birds upon Geralmente os pássaros encontrados Marajo are of different varieties em Marajó são de variedades difefrom those found about Pará, and rentes daqueles encontrados no Pará 
upon the Main. The Chatterers are e no continente. Os sabiás não são not seen there; the Toco Toucan vistos aqui; o tucano-toco ocupa o takes the place of the Red-billed ; lugar do Tucano-de-peito-branco; o the Cayenne Manikin, whose head uirapuru, cuja cabeça e ombros são and shoulders are bright red, is de um vermelho vivo, é tão comum as common as the White-capped quanto o uirapuru-de-chapéu-branelsewhere; Black-backed Yellow co em outros lugares; os corruOrioles, Icterus jububu, are piões, Icterus jububu, são extremaextremely abundant; as are also the mente abundantes, assim como os Mango Humming Bird, T. mango; beija-flores, T. mango; o beija-flor the Ruby and Topaz, T. moschitus; -brilho-de-fogo, T. moschitus; o Swallow-tailed, T. fortificatus; gavião-tesoura, T. forficatus; papaBlack-breasted, T. gramineus; and gaio, T. gramineus, e muitas outras many other varieties of this family. variedades dessa família.

Opposite Jungcal, and in view Em frente ao Juncal, visível da from the shore, is the Island of praia, está a Ilha Mexiana, com vinMixiana, twenty-five miles in te e cinco milhas ${ }^{15}$ de comprimento, length, and resembling Marajo in lembrando Marajó em suas caracits characteristics. This is entirely terísticas. Este território pertence the property of Srs. Campbell inteiramente aos senhores Campbell and Pombo, the proprietors of the e Pombo, os donos da propriedade Jungcal estate, and here they have Juncal, e aqui eles possuem muitos many thousand cattle. milhares de gado.

Upon Mixiana are Indian burial Em Mexiana, existem cemitérios inplaces, and from these are disinterred dígenas, de onde são desenterradas urns of great size, containing bones grandes urnas contendo ossos e váand various trinkets. Unfortunately, rias bugigangas. Infelizmente o temour time would not allow us to po não permite que visitemos essa visit that island, or we should ilha, ou teríamos que fazer grande have been at the pains of exploring esforço para explorar esses interesthese interesting remains. We saw, santes artefatos. Vimos, contudo, however, one of the jars at Jungcal. alguns desses vasos no Juncal. SeSimilar burying places are found in pulturas similares são encontrados 
various parts of Brazil and Paraguay, and the ancient method of interment in most of the tribes was the same.

Beyond Mixiana, is the much larger island of Caviana, and many other islands, of considerable size, are strewn over the mouth of the river.

Upon the opposite shore is the town of Macapá, said to contain the finest fort in Brazil. The situation is considered unhealthy, and foreigners rarely visit there. Sailing from Pará to Macapá, one passes more than forty islands. Between Macapá and Marajo is seen in its perfection the singular phenomenon, known as the Bore, or Pororoca, when the flood tide, at the instant of its turning, rolls back the waters of the river in an almost perpendicular wall. Condamine, many years ago, described the sea as " coming in, in a promontory from twelve to fifteen feet high, with prodigious rapidity, and sweeping away every thing in its course.' No one knows of such terrible phenomena now-a-days. We inquired of several persons accostumed to pilotting in the main channel, and of others long resident in the city and familiar with the wonders of the province, but none em várias partes do Brasil e Paraguai, e o antigo método de enterrar era o mesmo na maioria das tribos.

Depois de Mexiana, fica a ilha da Caviana, bem maior que aquela, e muitas outras, de tamanho considerável, estão espalhadas ao longo da foz do rio.

$\mathrm{Na}$ outra margem fica a cidade do Macapá, que possuiria o mais belo forte do Brasil. O atual cenário é considerado insalubre, e os estrangeiros raramente visitam aquela cidade. No trajeto do Pará ao Macapá pelo rio passa-se por mais de quarenta ilhas. Entre Macapá e Marajó é visto em sua perfeição o fenômeno conhecido como Pororoca ${ }^{16}$, quando a maré alta, no instante de sua virada, arrasta as águas do rio quase como se fossem uma parede perpendicular. Condamine, muitos anos atrás, descreveu o mar como "vindo, em um promontório de doze a quinze pés ${ }^{17}$ de altura, com rapidez prodigiosa, e varrendo tudo o que encontrasse em seu curso." Ninguém sabe de tão terríveis fenômenos hoje em dia. Perguntamos a muitas pessoas acostumadas a pilotar no canal principal e a outras que residem há muito tempo na cidade e são familiarizadas com as maravilhas da província, mas nenhuma delas ouviu 
of them had known the water to rise falar de as águas subirem acima de above the height of five feet, even cinco pés ${ }^{18}$, mesmo com a mudança at the spring tides. A canoe of any da maré. Nenhuma canoa do tamanho size is in no danger, her bow being que for corre perigo, estando sua proa turned to the flood.

virada para o fenômeno.

Early in the morning, we Cedo de manhã acompanhamos o accompanied Mr. Hauxwell to a Sr. Hauxwell até uma árvore na tree, upon which a pair of Tuyuyus qual um casal de tuiuius estava fawere Building their nest. A nimble zendo seu ninho. Um indígena veloz Indian climbed the tree, but the nest subiu na árvore, mas o ninho estawas unfinished. It was thirty feet va inacabado. Ficava a trinta pés ${ }^{19}$ from the ground, composed of large do chão, feito de grandes gravetos; sticks ; and looked from below, big e, olhando de baixo, era grande o enough for the man to have curled suficiente para que aquele homem himself in.

pudesse se agachar lá dentro.

We left Jungcal for the rookery, Partimos do Juncal para a colônia de about nine o'clock, with the aves por volta das nove horas, duranflood tide, in a montaria, with a te a maré alta, em uma canoa com couple of guides. They were men um par de guias. Estes eram trabalhaof the estate, and looked upon dores da propriedade e consideravam the adventure as most lucky for a aventura um golpe de sorte. Pondo them. Making pleasure subservient em prática o ditado "primeiro o deto business, they cararied their ver depois o prazer" eles carregavam harpoons for fish or alligators, arpões para os peixes ou jacarés, e and baskets for young birds. cestas para pássaros novos. Assim Immediately after leaving the que partimos da terra, espantamos landing, we startled a Cigana from uma cigana de seu ninho nos arbustos her nest, in the low bushes by the baixos junto à água. $\mathrm{O}$ rio estreitavawater. The stream grew more and se cada vez mais, serpenteando em more narrow, winding in every todas as direções. O topo de altas árdirection. Tops of tall trees met vores encontrava-se por sobre nossas over our heads, countless flowers cabeças, incontáveis flores enchiam o filled the air with perfume, and the ar de perfume e a luz e sombra brin- 
light and shade played beautifully among the green masses of foliage.

Upon the trees were perched birds of every variety, who flew before our advance, at short distances, in constantly increasing numbers, or curving, passed directly over us ; in either case, affording marks too tempting to be neglected. Upon some topmost limb, the Great Blue Heron, elsewhere shyest of the shy, sat curiously gazing at our approach. Near him, but lower down, Herons, white as driven snow ; some, tall and majestic as river naiads, others, small and the pictures of grace, were quietly dozing after their morning's meal. Multitudes of Night Herons, or Tacarés, with a loud quack, flew startled by ; and, now and then, but rarely, a Boatbill, with his long plumed crest, would scud before us. The Snake-bird peered out his long neck, to discover the cause of the general commotion ; the Cormorant dove from the dry stick, where he had slept away the last hour, into the water below ; swimming with head scarcely visible above the surface, and a ready eye to a treacherous shot. Ducks rose hurriedly, and whistled away ; Curassows flew timidly cavam lindamente por entre as verdes massas da folhagem.

Por sobre as árvores havia toda variedade de pássaros empoleirados, os quais voavam ante nosso avanço, a curtas distâncias, em números cada vez maiores, ou curvando-se, passavam diretamente sobre nós; em ambos os casos, deixando marcas tentadoras demais para serem ignoradas. Pousada sobre algum dos galhos mais altos, a grande-garça-azul, em outros lugares a mais tímida de todas, assistia curiosamente a nossa aproximação. Próximo a ela, mais abaixo, havia garças brancas como neve; algumas, altas e majestosas como náiades dos rios, outras, pequenas e graciosas, cochilavam tranquilamente após a refeição da manhã. Um grande número de socós dorminhocos, ou taquiris, voava assustado em meio a altos grasnidos; e, de vez em quando, embora raramente, um arapapá, com sua crista coberta por longas penas, disparava diante de nós. A anhinga colocava seu longo pescoço para fora, tentando descobrir a causa da comoção geral; o biguá mergulhou do graveto seco em que tinha dormido na última hora na água; nadando com sua cabeça quase imperceptível acima da superfície 
to the deeper wood; and fearless Hawks, of many varieties, looked boldly on the danger.
With a noise like a falling $\log$, an alligator would splash into the water from the bank, where she had been sunning herself, or looking after her nest ; and often, at once, half a dozen huge, unsightly heads were lifted above the surface, offering a fair, but not always practicable mark for a half-ounce ball. Occasionally, a whole family of little alligators, varying in length from six to eighteen inches, would start out of the leaves instinctively, some, plumping themselves in, as the examples of their respected mammas had taught them ; others, in their youthful innocence, standing gazing at us, from the top of the bank ; but with more than youthful cunning, ready also to plump in at the least motion towards raising a gun. At frequent intervals, the beaten track from the water, disclosed the path of some of these monsters ; and a pile of leaves, just seen through the trees, showed clearly the object of their terrestrial excursions. e com o olhar atento para um tiro traiçoeiro. Os patos levantaram-se apressadamente e passaram zunindo; mutuns voavam timidamente para dentro da floresta; e os destemidos gaviões, de variados tipos, olhavam com ousadia para o perigo.

Com um focinho parecido com um tronco caído, um jacaré pulou da margem do rio, onde se banhava ao sol ou cuidava de seu ninho, para dentro d'água; e, com frequência, de repente, meia dúzia de cabeças enormes e desagradáveis emergiam superfície, oferecendo um alvo promissor, mas nem sempre praticável, para um tiro. A cada certo tempo, toda uma família de pequenos jacarés, variando entre seis e dezoito polegadas $^{20}$ de tamanho, começariam a sair do meio das folhas instintivamente, alguns submergindo, como suas respeitáveis mães lhes haviam ensinado; outros, devido à inocência da juventude, permaneciam imóveis olhando para nós da margem, mas com mais que astúcia juvenil, prontos para submergir na água ao menor sinal de pegarmos em uma arma. A frequentes intervalos, a trilha agitada da água revelava o caminho de alguns desses monstros; e uma pilha de folhas, apenas vistas através das árvores, mostrava 
claramente o objetivo da excursão terrestre deles.

As we neared the rookery, after

À medida em que nos aproximáa two hours' pull, the birds were vamos da colônia de aves, depois more and more abundant ; and the alligators more and more bold, scarcely minding our approach, and only learning caution, by repeated applications of leaden balls. The frequent proximity of the King Jacarés, offered many opportunities to the harpooner in the bow ; but we learned, by his ill siccess, that these autocrats cared verey little for punches in the ribs.

de duas horas de viagem, as aves se tornavam mais e mais abundantes, e os jacarés, mais e mais ousados, pouco se importando com a nossa aproximação, aprendendo a ter cuidado com os repetidos disparos de balas de chumbo. A frequente aproximação do jacaretinga oferecia muitas oportunidades para o arpoador na proa, mas aprendemos, pela falta de êxito deste, que aqueles autocratas não davam a mínima para golpes em suas costelas.

Turning suddenly, we left the Fazendo uma curva repentina, deixabordering forest for a canebrake, mos a floresta das proximidades em and instantly broke full upon the direção a um canavial, e instantanearookery. In this part, the Scarlet mente entramos por completo na coIbises, particularly, had nested ; lônia de aves. Nessa parte, os íbises and the bended tops of the canes -escarlates, particularmente, tinham were covered by half-grown birds in their black plumage, interspersed with many in all the brilliance of age. They seemed little troubled at our approach, merely flying a few steps forward, or crossing the stream. Continuing on, the flocks increased in size; the red birds became more frequent, the canes bent beneath their weight like cresciam em tamanho; os pássaros 
reeds. Wood Ibises and Spoonbills, began to be numerous. The nests of all these, filled every place where a nest could be placed ; and the young Ibises, covered with down, and standing like so many Storks, their heavy bills resting upon their breasts and uttering no cry, were in strong contrast to the well-feathered Spoonbills, beautiful in their slightly roseate dress, and noisily loquacious. Passing still onward, we emerged from the canes into trees ; and here the White Herons had made their homes, clouding the leaves with white. Interspersed with these, were all varieties mentioned before, having finished their nesting, and being actively engaged in rearing their young. We had sailed above a mile, and at last, seeming to have approached the terminus we turned and went below a short distance to a convenient landing, where we could pursue our objects at leisure. The boatmen, at once, made their dispositions for basketing the young birds ; and soon, by shaking them down from the nests, and following them up, had collected as many as they desired. We wandered a long distance back, but the nests seemed, if any thing, more plentiful, and the swarms of young more dense. At the sound of the gun, the birds vermelhos tornavam-se mais frequentes, as canas curvavam-se como junco sob o peso delas. Tuiuiús e colhereiros começavam a se tornar numerosos. Os ninhos destes ocupavam todos os lugares possíveis; e os jovens íbises, cobertos de penugem e ficando de pé como muitos jabirus, seus bicos pesados repousando sobre o peito e sem fazer qualquer barulho, contrastavam fortemente com os colhereiros cobertos de penas, belos em seu vestido levemente rosado e ruidosamente loquazes. Ainda seguindo adiante, emergimos do canavial em meio a árvores, e aqui as garças-brancas-grandes construíram seu lar, cobrindo as folhas de branco. Em meio a essas aves havia todas as variedades mencionadas anteriormente, as quais terminavam de construir seus ninhos e empenhavam-se ativamente em cuidar dos mais jovens. Havíamos navegado cerca de uma milha ${ }^{21} \mathrm{e}$, finalmente, parecendo termos alcançado o ponto final, viramos e seguimos a uma curta distância em direção a um lugar conveniente onde poderíamos buscar nossos objetivos livremente. Os barqueiros imediatamente se dispuseram a capturar as aves mais jovens, e em pouco tempo, ao sacudi-las dos ninhos e depois alcançá-las, haviam recolhido tantas quanto desejavam. 
in the immediate vicinity, rose in a Vagueamos uma longa distância de tumultuous flock; and the old ones volta, mas os ninhos pareciam mais circled round and round, as though numerosos, e a massa de filhotes ainpuzzled to understand the danger da mais densa. Ao disparo da arma, they instinctively feared. In this as aves nas proximidades imediatas way, they offered beautiful marks começaram a voar em um bando tuto our skill ; and the shore, near the multuado; as mais velhas rodavam e canoe, was soon strewed with fine rodavam, como que confusas para specimens. Evidently, this place entender o perigo que instintivahad been for many years, the haunt mente temiam. Dessa maneira, elas of these birds. Not a blade of grass ofereciam um belo alvo para a nossa could be seen ; the ground was habilidade; e a margem próxima à smooth and hard, and covered with excrement.

canoa em pouco tempo estava coberta de ótimos exemplares. Evidentemente, esse local tinha sido por muitos anos o refúgio dessas aves. Não se podia ver uma folha de grama e o chão estava liso e duro, coberto de excremento.

Occasionally, and not very rarely, a young heedless would topple into the water, from which the noses of alligators constantly protruded. Buzzards, also, upon the bank, sunned themselves and seemed at home ; and not unfrequently, a hungry Hawk would swoop down, and away with his prey almost unheeded.

We were amused by the manner of Ficamos maravilhados com a mafeeding the young Scarlet Ibises. In neira que os filhotes de íbis-escarthe throat of the old female bird, late eram alimentados. Na garganta directly at the base of the lower da fêmea, bem na base da mandí- 
mandible, is an enlargement of the bula inferior, existe um alargamenskin, forming a pouch, which is to de pele que forma uma bolsa, a capable of containing about the bulk qual é capaz de conter o volume de of a small hen's egg. She would um pequeno ovo de galinha. A ave return from fishing on the shallows, voltava da pescaria na parte rasa do with this pouch distended by tiny rio com a bolsa cheia de peixes pefish, and allowed her young to pick quenos, os quais os filhotes podiam them out with their bills.

It was late when the tide turned and we hastened away, with the canoe loaded to overflowing. The birds seemed now collecting for the night. Squads of bright-colored ones were returning from the shore, and old and young were settling on the canes, over the water, like swallows in August. An alligator gave us an opportunity for a last show, and the air was black with the clouds of birds that arose, shrieking and crying. I never conceived of a cloud of birds before.

pegar usando os próprios bicos.

Era tarde quando a maré virou e nos apressamos para partir com a canoa transbordando de tão cheia. As aves pareciam agora se recolher para a noite. Grupos de pássaros com cores vivas retornavam da costa, e velhos e novos se acomodavam nas canas acima da água que nem andorinhas em agosto. Um jacaré nos deu oportunidade para um último tiro, e o ar ficou tomado de preto com as nuvens de pássaros que subiram chilreando e grasnando. Eu nunca tinha concebido uma nuvem de pássaros antes.

On our way down, we discovered the Em nosso caminho de volta, desnest of a Socco, the Tiger Bittern, cobrimos o ninho de um socó perto close by the water. The old bird da água. A ave, de um ponto alto, observed our motions for an ascent with indifference, when, up through the feathers of her wing, peered the long neck of a little fellow, intimating that we might as well be off ; for it was of eggs we were greedy. observava nossos movimentos com indiferença quando, dentre as penas de sua asa, saiu o longo pescoço de um pequeno camarada, o que nos intimou a ir embora, pois estávamos ávidos por ovos. 
Soon after, we arrived at the Logo depois, chegamos ao local que spot, which we had marked in the tínhamos marcado pela manhã, onde morning, where an alligator had um jacaré tinha feito seu ninho, e sem made her nest, and sans ceremonie, cerimônia começamos a revirá-lo em proceeded to rifle it of its riches. busca de suas riquezas. O ninho era The nest was a pile of leaves uma pilha de folhas e lixo com cerand rubbish, nearly three feet in ca de três pés de altura e quatro ${ }^{22}$ de height, and about four in diameter, diâmetro, lembrando com um galo de resembling a cock of hay. We palha. Não podíamos imaginar como could not imagine how or where ou onde aquele animal tinha reunido the animal had collected such a tamanha pilha, mas assim o era; e, heap, but so it was ; and, deep lá no fundo, bem próximo da superdown, very near the surface of the fície do solo, de uma cama regular, ground, from an even bed, came foi retirado ovo atrás de ovo, até forth egg after egg, until forty-five que quarenta e cinco destes tivessem had tolerably filled our basket. We kept a good look-out that the old one did not surprise us in our burglary, having read divers authentic tales of the watchful assiduity of the mother. But nothing appeared to alarm us, and we concluded, that, like others of the lizard family, alligators are merely anxious to make their nests, and trust to the fermented heat, and to Providence, for hatching and providing for their brood of monsters. These eggs are four inches in length, and oblong ; being covered with a crust rather than a shell. They are eaten, and our friends at the house would have persuaded us to test the virtues of an alligator omelette, but we mestíveis, e nossos amigos em casa respectfully declined, deeming our tentaram nos convencer a provar as 
reputations sufficiently secured by a breakfast on the beast itself. virtudes de uma omelete de jacaré, mas respeitosamente declinamos, julgando nossas reputações suficientemente seguras pelo café da manhã com o próprio animal.

A Ave Maria tinha tocado quando chegamos ao Juncal, e a satisfação que sentíamos ao final, os melhores dias desportivos que já tivemos, compensaram amplamente toda a fadiga. Como o barco em que viemos foi obrigado a retornar imediatamente, tivemos que nos despedir desse lugar encantador, onde teríamos nos contentado de passar um mês. Mas um dia como o que tínhamos passado nos compensou pelos inconvenientes de uma semana sobre a água.

Nós nos despedimos de nossos bons amigos pela manhã, aproveitando o final da maré baixa para chegar até o navio. Mas quando estávamos bem perto, a maré virou, as águas voltaram a encher e nós provavelmente revisitaríamos o Juncal. Contudo, seguindo pela margem e contando com canas suspensas, depois de um esforço exaustivo, alcançamos nosso objetivo, quase propensos a dar crédito ao Sr. Condamine. 
The crew were loading with the A tripulação fazia o carregamento cattle, which had been driven do gado, que tinha sido trazido no down the day before, and were dia anterior e agora estava confinow confined in the den. This was nado no curral. Este estava fechaenclosed on every side, but that do por todos os lados, menos na toward the water. A dozen men direção da água. Havia uma dúzia stood inside and out, some holding de homens lá, alguns segurando o the lasso, others ready to pull, the laço, outros prontos para puxar no instant the animal was caught, and instante em que o animal fosse capothers, still, were armed with sharp turado, e outros, parados, estavam goads, with which to force him armados com aguilhões afiados, onward. Some of the cattle showed com os quais forçariam o bicho a good Castilian spirit, and their rage seguir em frente. Alguns animais was several times with difficulty mostravam bom espírito castelhano, eluded by a leap to the friendly e sua fúria era, várias vezes, eludifence. Once in the water, their da com dificuldade pela cerca amistruggles were over. A rope was gável. Quando chegavam na água, fastened about their horns, and thus they were hoisted up until they were a luta terminava. Uma corda era amarrada em volta dos seus chifres above the hole in the deck made e desta maneira eles eram içados em to receive them. Below, they were direção à abertura no convés feisecured to side beams, and were ta para recebê-los. Por baixo, eles scarcely allowed room to move.

Putting out of the igaripé, for two days we were beating to windward, anchoring half the time, and being ancorar metade do tempo, e sendo tossed about in a way to make us sacudidos de maneira tal que amaldicurse all cattle boats. The poor çoamos todos os navios boiadeiros. victims in the hold fared worse As pobres vítimas no porão saiam-se than we, deprived of food and piores que nós; privadas de comida e drink, pitched back and forth with água, eram jogadas para frente e para every motion, and bruised all over trás a cada movimento, machucandoby repeated falls upon the rough se por inteiro por conta das repetidas 
floor. We lost all gusto for Pará quedas no chão duro. Perdemos todo beef. From Cape Magoary we had o gosto pela carne bovina do Pará. A a fine run, reaching Pará upon the partir do Cabo Maguari tivemos um third night. bom percurso, chegando ao Pará na terceira noite.

\section{Notas}

1. Aproximadamente 193 quilômetros.

2. De 96 a 128 quilômetros.

3. No texto de partida, o autor se refere a "tigres", termo empregado à época e que não se aplica hoje em dia, visto que não há tigres na Amazônia. A opção por usar o termo "onça" aqui é para evitar que se fale em "tigre negro" (black tiger) mais a frente, termo que é imediatamente seguido por "Felis onca" (onçapintada). Assim, de modo a manter um paralelismo de termos, empreguei onça de forma genérica.

4. Proprietário de terras na região de Marajó, inclusive da fazenda Juncal.

5. Aproximadamente $2.133600 \mathrm{~m}$.

6. Na pesquisa realizada, o outro termo popular encontrado para designar o animal foi jacaretinga. Não foi encontrada nenhuma forma próxima a do inglês King Jacarés.

7. Aproximadamente $6,096 \mathrm{~m}$.

8. Aproximadamente 7,62m.

9. Caffre, do árabe, designa originalmente africano não-muçulmano; contudo, como consequência da política de colonização, é usado para se referir a africanos negros de forma ofensiva tanto em português quanto em inglês.

Cad. Trad., Florianópolis, v. 41, $\mathbf{n}^{0}$ esp. 1, p. 149-173, jan/jul, 2021. 172 
10. Cerca de 6,7 metros.

11. De fato, Robert Southey nas notas do seu History of Brazil, Part I (1810), p.629, diz tratar-se de uma fábula e no texto, ele não se refere à cobra como "the anaconda" mas "this monster". https://babel.hathitrust.org/cgi/pt?id=ucm.5311 13572x\&view $=1$ up\&seq=649\&q1 = snake. Acesso em 10 de janeiro de 2021.

12. O texto fonte cita Musk Duck, o que foi mantido na tradução. Contudo, acreditamos que o autor pode ter trocado os nomes do Muscovy Duck (patoselvagem) nativo do México, América Central e América do Sul com o Musk Duck (pato-de-papada) nativo do sul da Austrália.

13. Cerca de 1,609 quilômetros.

14. Aqui Edwards parece tratar de John James Audubon, autor de The Birds of America, publicação seriada de 1827 a 1839. https://www.audubon.org/fieldguide/bird/fork-tailed-flycatcher. Acesso em 16 de janeiro de 2021.

15. Pouco mais que 40 quilômetros.

16. No texto-fonte, Edwards cita: (...) the singular phenomenon, known as the Bore, or Pororoca. Subtraímos bore, irrelevante para o leitor brasileiro.

17. Aproximadamente de 3,60 a 4,5 metros.

18. Aproximadamente 1,5 metro.

19. Aproximadamente 9,1 metros.

20. De 15 a 45 centímetros, aproximadamente.

21. Aproximadamente 1,6 quilômetro.

22. Cerca de 90 centímetros de altura e 120 centímetros de diâmetro.

23. Pouco mais de 10 centímetros.

Cad. Trad., Florianópolis, v. 41, n $^{0}$ esp. 1, p. 149-173, jan/jul, 2021. 173 